\title{
Factors of enterprise value - the privatization of 'Sidex Galati' Romania (case study)
}

\author{
Madalina Viorica ION (MANU) \\ The Bucharest University of Economic Studies, Bucharest, Romania \\ mvmadalina@yahoo.com
}

\begin{abstract}
The enterprise value is central in business transactions (i.e. mergers and acquisitions, entrance of new shareholders or exit, bank loans), privatization of state-owned companies, etc., when the seller and the buyer confront each other's business valuations trying to identify as many weaknesses as possible on the other side. Such important value as the enterprise' is not an exact figure that can be calculated with precision at a certain date for a certain company, but an approximation that both buyer and seller may consider in each other's attempt to close a good deal for himself/ herself. The valuation approach in this paper is a market method for business investments and comparable sales. This retrospective analysis of a major privatization in the Romanian steel industry - when the industry's 'giant' was sold by the Romanian State - aims to identify key factors of the enterprise value in the context of international transactions. This was a high-profile privatization of great significance for the European steel industry and this analysis aims to understand enterprise value in order to model it. For this purpose, the article takes into consideration the information available regarding the privatization of Sidex Galati, the relevant literature and the author's experience, supplemented by the information from the post-privatization evolution of the Romanian steel enterprise. As a result, the article draws lessons and concludes on determining factors of enterprise value, such as assets, solvency, company's history, cash flow, taxation etc., while the price transaction in the case of the privatization of Romanian steel enterprises was also influenced by exogenous factors, such as the steel market, the State's need for revenues, the controlling package of the company sold, etc.
\end{abstract}

Keywords: internationalization, globalization, privatization, strategy, shareholders, factors, business excellence.

\section{Introduction}

The article is a minor extension of the author's previous research on the factors of enterprise valuation ${ }^{1}$. The approach used is the retrospective analysis of a strategic privatization, making use of the public information regarding the global steelmaking leader, and the author's professional and life experience.

Back in 2000, the largest steelmaker in the Central and Eastern Europe (CEE) - Sidex Galați used to be depicted as 'the largest black hole of the Romanian economy', in the media. After the privatization, which was considered the most successful of all, a milestone in Romania's economic reforms, we are looking at the \#1 steel producer.

The article casts a critical eye on the company, and the research question is to identify the most important factors of the enterprise value in order to model this relation.

${ }^{1}$ http://www.upm.ro/ldmd/LDMD-05/LDMD\%2005\%20Social\%20Sciences.pdf 
The main hypotheses considered in this research is that the factors that determine the enterprise value should be considered mainly from the buyer's point of view (who finally pays the money or not); from this respect, the number of shares (i.e. the controlling percent) that the seller is going to give, and endogenous factors, such as the debts the company accumulated or expected cash-flow, are very important, rather than an asset view of the company.

\section{Literature review}

\section{Company internationalization}

In Romania, the largest steel maker in the CEE area - Sidex Galați was making heavy losses $\left(13,28\right.$ billion US $\$^{2}$ by 1995$)$ and the government wanted to sell it, yet save the jobs of 28,000 steel workers; the pro forma sales price was US\$54 million, on condition that the labor force was retained for at least five years and the new owners committed themselves to investments of US\$350 million (Marianne Beisheim, 2012).

Voinea and Dancau (2003) indicate that such a success story is the result of conditions such as: (i) a commodity type of industry, (ii) an industry in a consolidation process, (iii) existing demand for the company products, (iv) an investor with a global reach and a focus on emerging markets (editors M. Marinov, 2011); also seller's eagerness was essential for the group' success in the acquisitions' process (Policy Warning Report, Romania, 2003). Another strategic factor was the exemption from the $30 \%$ surcharge on steel imports imposed by the U.S.

At the time of privatization, Sidex, a centerpiece of Communist Romania's industry, was very vulnerable: bankrupt, relying on barter for its finished steel for raw materials, facing major technical problems, while its 27,000 employees were looking for a solution from the state. Given the industry turmoil, Sidex' difficult financial position and competitors' lack of interest, Mittal was probably the only potential investor with a global exposure (Daianu, 2004). The company was sold for $\$ 366$ million to an Indian entrepreneur who envisioned building the world's top steelmaking group by cheaply acquiring huge money-losing state-owned mills from governments desperate to remove them from state books and then by applying strict management techniques, by producing low-cost, lowerquality steel products and selling them through his global network (Green, 2002).

Before the year 2000, this company represented the largest single source of interenterprise arrears, so the injection of cash into the business and the elimination of barter, impacted positively on the company's suppliers and customers. The privatization of Romania's largest steel mill was assisted by EBRD financing in the form of a one-year €113 million working capital facility, €67 million of which was disbursed in November 2001 (EBRD, 2001).

The majority of studies on the impact of privatization consider the profitability, real output, investment, productivity, and employment and the results on improved efficiency are particularly robust when the firm operates in a competitive market, and that deregulation speeds up convergence to private sector levels (OECD, 2003). Megginson and Netter (2001), in their survey of microeconomic empirical studies, show that privatization acts to enhance enterprise performance (John Bennett, 2006).

${ }^{2}$ average USD (ROL/USD) of 2033,28 (in 1995) 
With respect to company's net income - obtained after assuming certain accounting hypotheses regarding expenses and revenues in order to identify which expenses were necessary to obtain the revenues, such as the scheduling of expense accruals, the treatment of depreciation, calculating the product's cost, allowances for bad debts, etc., it can give us adequate information, while the cash flow is considered an objective measure, i.e. a company "generates wealth" for its shareholders when the cash flows improve (Fernandez, IESE Business School, University of Navarra, 2006).

Similarly, companies calculate and publish EBITDA ${ }^{3}$, which is considered to have several limitations that become more crucial as risk tolerance among high-yield investors increases and underwriting standards and financial covenants loosen (i.e. investor demand remains strong for bonds issued by companies with weak balance sheets, so companies negotiate aggressive adjustments to EBITDA to depict lower leverage and a seemingly better credit profile). Moody's identified critical failings of using EBITDA, such as: it ignores changes in working capital and overstates cash flow in periods of working capital growth; it does not consider the amount of required reinvestment - especially for companies with short lived assets; it is an inadequate standalone measure for comparing acquisition multiples; ignores distinctions in the quality of cash flow resulting from differing accounting policies - NOT all revenues are cash. EBITDA is not well suited for the analysis of many industries because it ignores their unique attributes. EBITDA is typically used in financial maintenance, restricted payment, debt incurrence and other covenants that affect a company's liquidity, debt capacity and use of cash flow (Moody's, 2014).

EBIDTA was originally used for financial analysis to evaluate companies facing economic stress, then extended to calculate the value of companies in leveraged buy-outs in the 1980s, and then to a very broad group of companies in the 1990s (Kantor, 2008).

Modeling of market microstructure problems - whereby investors' preferences and desires are translated into financial market transactions, i.e. market rigidities or frictions can imply that current asset prices do not fully reflect future expected cash-flows - was studied by Madhavan (2000), O'Hara (1995), Harris (2002) and Hasbrouck (2007) (Brooks, Introductory Econometrics for Finance, 2014).

\section{Methodology}

This qualitative research is a minor extension of the author's previous research ${ }^{4}$ aiming to identify key factors of enterprise value.

As I have shown previously5, a very good and realistic valuation approach for business investments is the market-based method (comparable sales and transactions). The analysis of the terms of Sidex privatization shows major differences in the price paid for the controlling stake of Sidex and in the other terms of the privatization, as in Figure 1, most

\footnotetext{
${ }^{3}$ earnings before interest, taxes, depreciation and amortization

4 Presented at 'The Twelfth International Conference on Economic Cybernetic Analysis: Economic and Social Aspects of the European Union Consolidation - EUnIT2017, November 24-25, 2017

5 'How much is the listed enterprise worth? The price multipliers' approach', http://store.ectap.ro/suplimente/International_Finance_and_Banking_Conference_FIBA_20 17_XV.pdf p.77
} 
probably due to very little negotiation power of the seller who lacked the global picture of the steel and its advantages.

\begin{tabular}{|c|c|c|c|}
\hline $\begin{array}{l}\text { Company } \\
\text { acquired }\end{array}$ & $\begin{array}{l}\text { Production } \\
\text { capacity } \\
\text { (million } \\
\text { tonnes)/ no. } \\
\text { of employees }\end{array}$ & $\begin{array}{c}\text { Price for } \\
\text { controlling stake, } \\
\text { mil. USD }\end{array}$ & $\begin{array}{l}\text { Total investment } \\
\text { commitment, } \\
\text { (incl. price paid } \\
\text { outright), } \\
\text { mil. USD }\end{array}$ \\
\hline \multirow[t]{2}{*}{ Sidex } & 4.5 & 70 & 500 \\
\hline & 27000 & & \\
\hline \multirow{2}{*}{$\begin{array}{l}\text { Nova Hut } \\
\text { (Czech Rep.) }\end{array}$} & 2.7 & 20 & 905 \\
\hline & 12000 & & \\
\hline \multirow{2}{*}{$\begin{array}{l}\text { Karmeł } \\
\text { (Kazakhstan) }\end{array}$} & 6.3 & 450 & 800 \\
\hline & 72000 & & \\
\hline \multirow[t]{2}{*}{ Mexicana } & 4.0 & 25 plus 195 in & n.a. \\
\hline & n.a. & $\begin{array}{l}\text { government } \\
\text { bonds }\end{array}$ & \\
\hline
\end{tabular}

Figure 1.Comparison between some of the acquisitions of the controlling package Source: (Policy Warning Report, Romania, 2003).

As in figure 1, similarly with debt-burdened Ispat Mexicana bought by Ispat International 6 for $\$ 25$ million cash and the purchase of $\$ 195$ million in Mexican government bonds at near junk-level interest rates (Green, 2002), the initial pro-forma sales price was less than Sidex turnover (of 73 and 74 mil.US\$ for the years 2000 and 1999).

The financial indicators (in US\$, for comparability) of the Romanian steel producer evolution, for the period 1996-2016, help us understand the company financial vulnerability at the time of privatization, as in figure 2 .

As we can notice in figure 1 above, the production capacity (and its wear degree) is of major importance, due to the significant investments it encompasses, and that is why it will be considered in an enterprise value model for steelmaking companies.

\footnotetext{
${ }^{6}$ Ispat (the Hindi word for "steel") is the industry's first global steel manufacturer, with operations in the United States, Ireland, Mexico, Canada, the Caribbean, Germany, and France (International Directory of Company Histories, 2000); it used to be considered the world's fastest growing steel company (Ispat International N.V., 1997).
} 


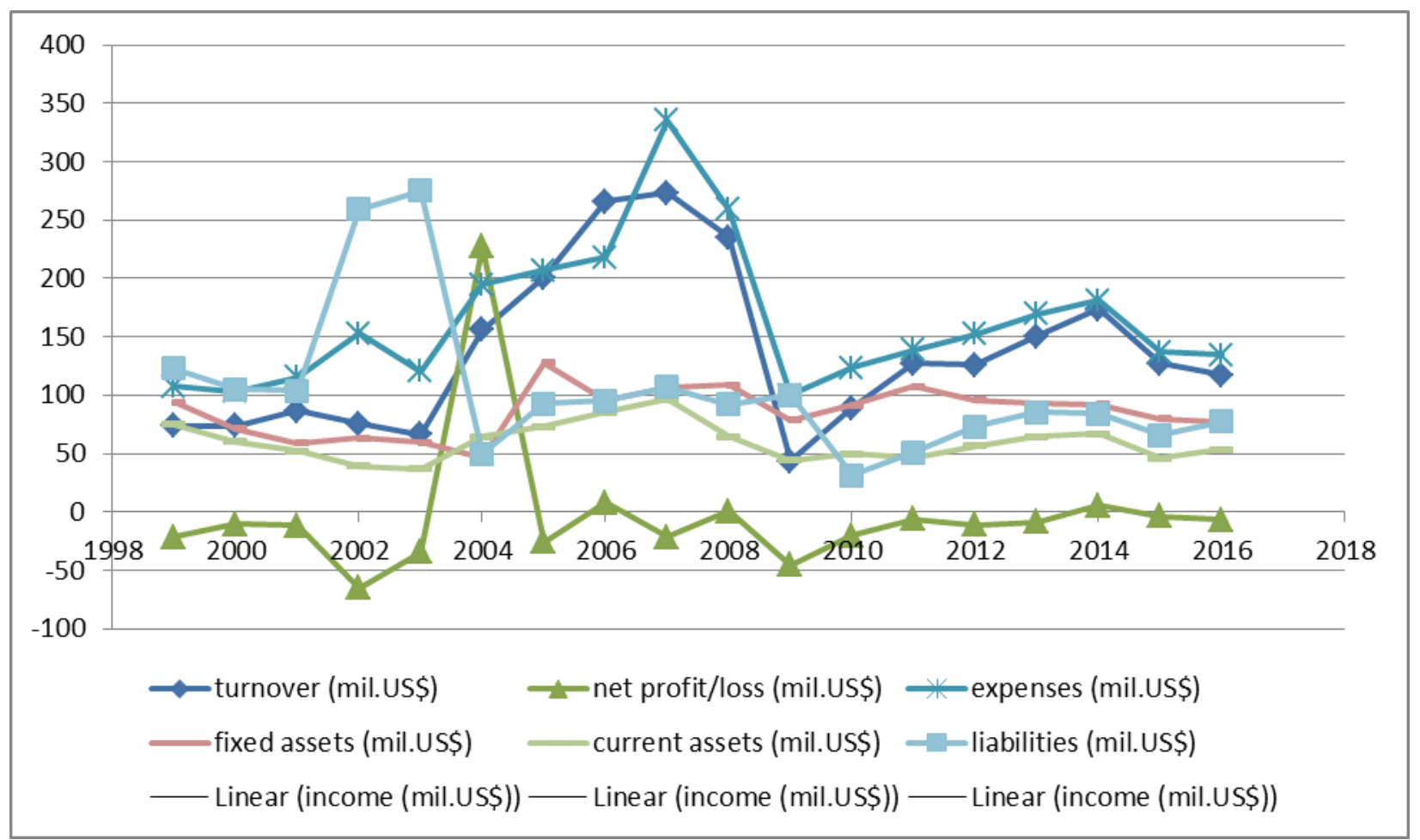

PICBE | 470

Figure 2. The evolution of income and other financial indicators

Source: author's research.

The normalization of financial statements, required as the first step for benchmarking, business valuation, or merger and acquisition, comes in many ways based on the appraiser's professional judgment.

The net income, cash flow and financial revenue have traditionally been indicators of the company value, buyer's decision being usually grounded on: the cash-flow predictions and expectations, clients and market concentration in a strategic decision to become the global leader (Fernandez, Cash flow is a Fact. Net income is just an opinion, 2017). Sidex total assets (over 1.1 billion US\$) at the time of the acquisition did not raise to this value the price paid, which covers for the equity derived from the debt-equity swap: the price of 70 million US\$ for 90\% controlling stake in Sidex (Policy Warning Report, Romania, 2003).

After the privatization (2001), the business has been rethought and restructured ${ }^{7}$, by means of: cost-cutting methods, voluntary departure schemes for the employees, sound branding and rebranding, vigorous marketing and market positioning; renegotiated the long-term supply contracts for the 14 million metric tons of raw materials that Sidex consumes annually, using new contacts and computer pricing models; old debts were renegotiated toughly. It was considered that geographical coverage and the correct application of basic modern management principles (Green, 2002), with zero tolerance for theft/ illegal acts in the company are important elements of success.

Revealing an ambitious endeavor to become the world's largest steel and mining company, the successful consolidation strategy with many major acquisitions all over the world, including Sidex (Romania) in 1999 (ArcelorMittal), lead up in 2006, to the takeover of Western European steel maker Arcelor (Spain, France, and Luxembourg) at a cost of

${ }^{7}$ Such methods have been presented at EUnIT2017, November 24-25, 2017 
$€ 40.37$ /share (approximately $\$ 33$ billion), a premium of approximately $100 \%$ excluding dividend on the closing price of Arcelor shares; the resulting shareholder structure was $50.5 \%$ for the shareholders of Arcelor and $49.5 \%$ of Arcelor-Mittal for Mittal Steel, respectively.

The new group principles - an integrated model based on leadership in high value added steel, capturing growth in low cost developing markets, industrial excellence through state of the art assets sustained by sound capital expenditure levels, upstream vertical integration for cost leadership, commercial leadership based on strong distribution channels, high profitability targets including a 30\% dividend payout target as part of a broader effort to maximize shareholder returns, sound capital structure (ArcelorMittal, 2006) seem still successful.

In spite of the limitations of EBITDA listed above, the group calculates and publishes EBITDA - defined as operating income plus depreciation, impairment expenses, restructuring and exceptional charges/income, as shown below in Figure 3.

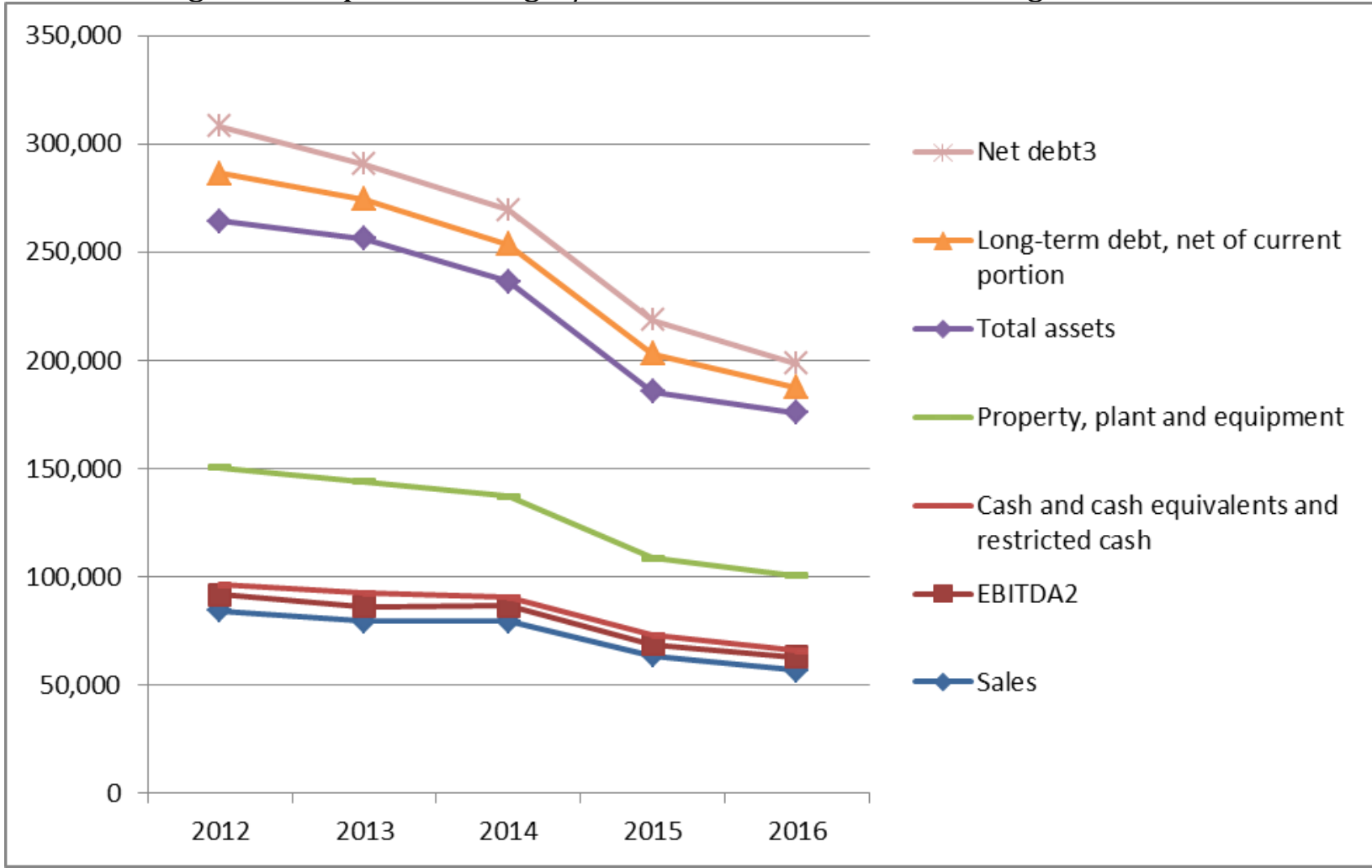

Figure 3. ArcelorMittal financials (US\$ millions) between 2012-2016

Source: author's processing using (ArcelorMittal).

EBITDA can be a proxy for the cash flow, as the figure above shows and it is a better measurement for companies whose assets have longer lives, according to Moody's.

In fig. 3, the net debt is calculated as it follows:

$\mathrm{ND}=\mathrm{D}-\mathrm{C}$

Where $\mathrm{D}=$ long-term plus short term debt,

$\mathrm{C}=$ cash and cash equivalents, restricted cash and short-term investments, excluding those held as part of assets/liabilities held for sale (ArcelorMittal).

The group has grown exponentially to a market cap of \$2.26B (ArcelorMittal, 2017). 
Enterprise value (EV) can be calculated as it follows, based on the market capitalization ${ }^{8}$ - weighted average common shares outstanding multiplied by share price (ArcelorMittal):

EV=M.Cap.+ND+i-I
Where ND= net financial debt,

$\mathrm{i}=$ minority interest,

I= investments/others.

\section{Results and discussions}

The article uses comparable sales and transactions to identify key elements relevant for the enterprise value, such as the price for the controlling stake.

The privatization opened up the Romanian market to capital and expertise, which can increase the revenues, to management skills and technology that help improve corporate efficiency and performance, and develop links to export markets (OECD, 2003).

The shareholding structure of the privatized companies is very important, for example, the owner of Mittal Steel is the chairman and CEO and with his family owns $40 \%$ of the shares and voting shares in the company (ArcelorMittal, 2012). Below, in figure 3, the shareholders structure of ArcelorMittal Hunedoara, another company of the no.1 steel group, shows the owner of the company.

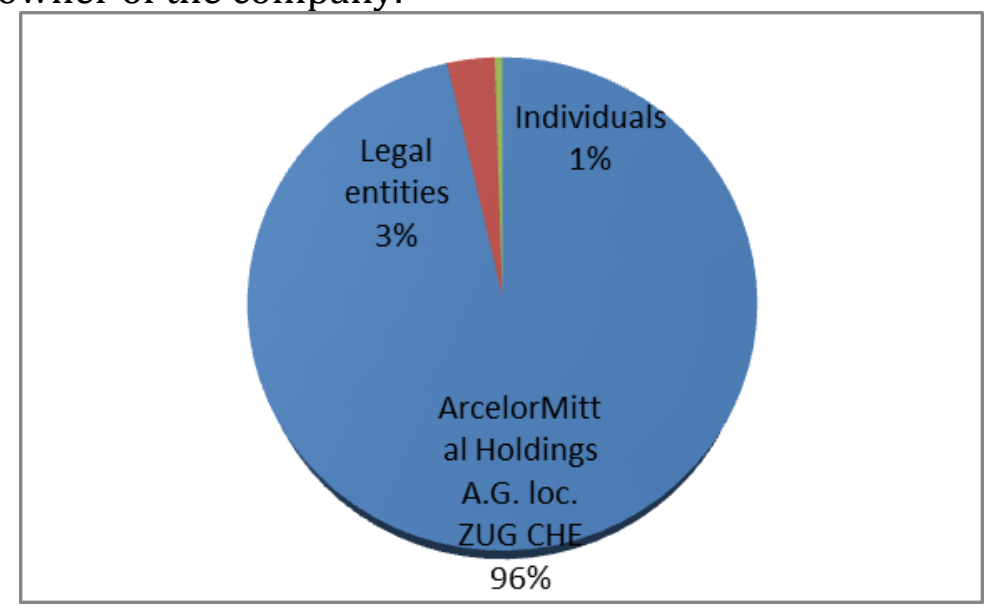

Figure 4. The shareholders structure of ArcelorMittal Hunedoara

Source: (ArcelorMittal Hunedoara).

Arrangements and mechanisms to retain some degree of control in order to protect the newly privatized companies from the rigidities of the competition for corporate control, especially in strategic sectors of national interest include: golden shares; stable core of shareholders; or retention of a controlling interest in the company (OECD, 2003).

As opposed to the vast experience in steelmaking of the buyer of Sidex, the lack of knowledge of the field of other possible steel-mill buyers, the production surplus that has pushed down the steel prices, or the financial performance and stock prices of steel makers, as it can be observed in figure 2 for the years before privatization and onwards are factors that did not favor the selling price of the company; similarly, in 2001, Ispat International lost $\$ 312$ million, compared with a profit of $\$ 99$ million in 2000 , sales fell 16 percent, to

${ }^{8} € 27.99 B$ at 22.12.2017 (ArcelorMittal, 2017) 
$\$ 4.49$ billion, and its shares have fallen to $\$ 2.95$ a share, from an offering price of $\$ 30$ in 1997 (Green, 2002).

Also the big differences in the transaction terms show how the companies' difficulties, such as the big losses and lack of investments, counted in the final price. Such element, as the controlling stake (\%), will be considered in a model of enterprise value.

While, previously, Communist managers preferred to produce at any cost, after privatization, the end of the barter system was possible by the will of an ambitious owner who had the power to correctly apply the management principles (Green, 2002). Besides the control being concentrated in only one hand, the facilities obtained, such as the debt equity swap - an unusual practice in the acquisition of heavily indebted companies - erased overdue debts at a discount premium, giving the buyer the opportunity to run the business without historic debts (Policy Warning Report, Romania, 2003).

The amount of existing debts (at the moment t-1) and/or the debts at business restart will also be considered in a model of enterprise value. Sidex liabilities were diminished ${ }^{9}$ by 770 million US\$, which exceeds 69 million US\$ (at a rate of 9 cents $/ \$$ - the discount rate applied in the debt/equity swap) (Policy Warning Report, Romania, 2003).

\section{Conclusion}

In the steel market - with standardized products, price and/or quality of the steel products make the rules and any business valuation must consider the industry specific.

The article analyzes information relevant to the buyer, which includes: the market, the company history (which usually translates into existing relations with clients and/or intermediary traders, traditional presence on certain markets, both domestic and export), initial investments, facilities and /or exemptions offered by the state and last but not least the privatization method and the controlling stake that the buyer gets. Understanding the importance of certain factors of enterprise value, possible applications and extensions of this research can be a new model for the enterprise value.

Globalization is in the nature of the steel and the industry needed consolidation. An ambitious investor has identified and capitalized on market opportunities, buying existing, badly managed plants, revealing the investor appetite for companies with potential. In 2001, Sidex Galați value at privatization was US\$54 million ${ }^{10}$, which was less than the company's turnover. At present the group reached a market cap of \$2.26B (ArcelorMittal, 2017).

Major limitations of the present research refer is data scarcity, making the analysis and comparison very difficult. The research for the relevant factors for enterprise value needs to be carried on, in the attempt to model it.

\section{References}

Adevărul Moldova. (2011, 11 28). Galați. Retrieved 11 2017, from

http://adevarul.ro/locale/galati/cresterea-descresterea-combinatului-siderurgicgalati-s-au-implinit-45-ani-ceausescu-taiat-panglica-foto1_50ad7af17c42d5a66395f38c/index.html

\footnotetext{
${ }^{9}$ Under the government ordinance no. 119/2001, known as Sidex' Ordinance

${ }^{10}$ plus investments of US\$350 million
} 
ArcelorMittal Galati. (n.d.). About us. Retrieved 2017, from http://galati.arcelormittal.com/about-us.aspx?sc_lang=en

ArcelorMittal galati. (n.d.). Company History. Retrieved 11 2017, from http://galati.arcelormittal.com/about-us/company-history.aspx?sc_lang=en

ArcelorMittal Hunedoara. (n.d.). Information for shareholders. Retrieved 12 2017, from http://www.arcelormittalhunedoara.ro/ro-RO/S_A_en.html

ArcelorMittal. $(2006,06)$. Arcelor recommends improved Mittal Steel offer. Retrieved 12 2017, from http://corporate.arcelormittal.com/news-and-media/pressreleases/archive/2006/jun/25-06-2006?lang=english

Arcelormittal. (2009, 02 11). Previous results. Retrieved 12 201, from http://corporate.arcelormittal.com/ /media/Files/A/ArcelorMittal/news-andmedia/press-releases/2009/February/128-27-2-ENArcelormittalReportsFullYearAndFourthQuarter2008Results.pdf

ArcelorMittal. (2012, 09 30). Shareholding structure. Retrieved 12 2017, from https://web.archive.org/web/20121005074851/http://www.arcelormittal.com/co $\mathrm{rp} /$ investors/corporate-governance/shareholding-

ArcelorMittal. (2017, 12 22). Share monitor. Retrieved 12 22, 2017, from http://corporate.arcelormittal.com/investors/investor-toolkit/share-monitor

ArcelorMittal. (n.d.). Arcelor recommends improved Mittal Steel offer. Retrieved 12 2017, from http://corporate.arcelormittal.com/news-and-media/pressreleases/archive/2006/jun/25-06-2006?lang=english

ArcelorMittal. (n.d.). Fact book. Retrieved 12 2017, from http://corporate.arcelormittal.com/ /media/Files/A/ArcelorMittal/investors/factbook/2016/factbook-2016.pdf

ArcelorMittal. (n.d.). Glossary of analyst model terms. Retrieved 12 2017, from http://corporate.arcelormittal.com/investors/investor-toolkit/glossary-of-analystmodel-terms

ArcelorMittal. (n.d.). Our history. Retrieved 12 2017, from Who we are: http://corporate.arcelormittal.com/who-we-are/our-history

Beisheim, M. E. U. (2012). Limits to Privatization: How to Avoid Too Much of a Good Thing : a Report to the Club of Rome. London: Earthscan.

Brooks, C. (2014). Introductory Econometrics for Finance. Cambridge: Cambridge University Press.

Daianu, D. (2004). Romania Since 1989: Politics, Economics, and Society. In H. F.Carey (Ed.), Romania Since 1989: Politics, Economics, and Society (p. 402). Oxford: Lexington Books.

EBRD. (2001). Annual report 2001. Retrieved 12 2017, from https://bg.uek.krakow.pl/ezasoby/ebor/ar/ar01.pdf

EBRD. (2001). Annual report 2001. Retrieved from https://bg.uek.krakow.pl/ezasoby/ebor/ar/ar01.pdf

Fernandez, P. (2006, 05). IESE Business School, University of Navarra. Retrieved 12 2017, from http://www.iese.edu/research/pdfs/DI-0629-E.pdf

Fernandez, P. (2017, 10 11). Cash flow is a Fact. Net income is just an opinion. Madrid, Spain. 
Green, P. S. (2002, 07 07). Betting Big On Reviving 'Black Holes'. Retrieved 12 2017, from THE BUSINESS WORLD: http://www.nytimes.com/2002/07/07/business/thebusiness-world-betting-big-on-reviving-black-holes.html.

International Directory of Company Histories. (2000). Ispat International N.V. History. Retrieved 2018, from http://www.fundinguniverse.com/company-histories/ispatinternational-n-v-history/.

Ispat International N.V. (1997). Annual Report 1997. Retrieved 2018, from https://ddd.uab.cat/pub/infanu/118750/iaMITTALSTEELa1997ieng.pdf.

John Bennett, S. E. $(2006,06)$. Working Paper: Methods of Privatization and Economic Growth in Transition Economies. Retrieved 11 2017, from http://hdl.handle.net/10419/140745 In M. Kantor, Valuation for Arbitration: Compensation Standards, Valuation Methods and Expert Evidence. Kluwer Law International.

Marinov, S. M. (2011). The Changing Nature of Doing Business in Transition Economies. Palgrave Macmillan.

Moody's. (2014, 11 20). Moody's Investor Service. Retrieved 12 2017, from https://www.moodys.com/research/Moodys-Used-and-Abused-EBITDA-remains-akey-measure-of--PR_313393.

Novus Via SRL Oradea. (n.d.). Xtreme Freelance. Retrieved 11 2017, from https://www.youtube.com/user/Customblogs/.

OECD. (2003). Privatising State-Owned Enterprises: An Overview of Policies and Practices in OECD Countries. ORGANISATION FOR ECONOMIC CO-OPERATION AND DEVELOPMENT.

Policy Warning Report, Romania. (2003, 05). Retrieved 12 2017, from http://sar.org.ro/files/May2003-Economy1.pdf.

SAP. (n.d.). What is ERP? (SAP) Retrieved 11 2017, from https://www.sap.com/products/what-is-erp.html.

TopFirme. (2017). TopFirme. (TopFirme) Retrieved 11 2017, from https://www.topfirme.com/afacere/arcelormittal-gala\%C5\%A3i-sa/6jjdf38dp/

Whited, H.-h. I. (n.d.). Normalization of balance sheets and income statements. Retrieved 11 2017, from Journal of Case Research in Business and Economics: http://www.aabri.com/manuscripts/10476.pdf. 